\title{
AFFIRMATIVE CONSENT VE SVĚTLE LISTINY ZÁKLADNÍCH PRÁV EU*
}

\author{
SABINA KRAJÍČKOVÁ
}

\begin{abstract}
Affirmative consent with respect to the Charter of Fundamental Rights of the EU
The article deals with a current topic regarding the principle of affirmative consent which means an explicit consent with a sexual intercourse with respect to Charter of Fundamental Rights of the EU. The first part is devoted to a legal definition of the affirmative consent and the analysis of its particular aspects. The following chapters comment on the legislative framework of this doctrine in the US and Europe. The last chapter is focused on the potential problems and risks that may arise when applying the policy of the affirmative consent.
\end{abstract}

Keywords: affirmative consent; no means no; yes means yes; sexual violence; rape; protection of victims of sexual offences; Charter of Fundamental Rights of the EU

Klíčová slova: výslovný souhlas; ne znamená ne; ano znamená ano; sexuální násilí; znásilnění; ochrana obětí sexuálních trestných činů; Listina základních práv EU

DOI: $10.14712 / 23366478.2018 .40$

\section{1. ÚVOD}

V době, kdy celý svět řeší kauzu \#MeToo, vznik hnutí Time’s Up a čím dál více se poukazuje na problém sexuálního násilí, se pomalu dostává do popředí nutnost formulovat požadavek souhlasného projevu vůle, z něhož lze jasně a explicitně vyvodit souhlas druhé osoby se sexuálním sblížením. Jako první ze zemí, která se rozhodla přijmout právní úpravu týkající se tzv. affirmative consent byla Kalifornie, a to konkrétně v univerzitním prostředí mezi vysokoškoláky, kde byla obecně míra sexuálního násilí a obtěžování označována jako vysoká. Následně přijalo stejné nebo obdobné opatření několik dalších států v USA. Tendence v Evropě jsou však ve srovnání s USA podstatně umírněnější. Přesto si nelze nepovšimnout, že problematice sexuálního násilí se v posledních letech věnuje velké množství speciálně zaměřených organizací a postupně členské státy mění své právní normy tak, aby více reflektovaly a odpovídaly požadavkům aktuální doby. Vzhledem k tomu, že výslovná právní úprava týkající se affirmative

* Tento výstup vznikl v rámci projektu Specifického vysokoškolského výzkumu 2017-2019 s názvem „Práv-
ní vědomí: pojem, formování, účinky se zvláštním zřetelem k působení Listiny základních práv Evropské
unie na právní vědomí v České republice“, č. 260 361, řešeného na Právnické fakultě Univerzity Karlovy. 
consent na úrovni evropského práva absentuje, budu se v tomto článku zabývat tím, zda lze z unijního práva, a to především z Listiny základních práv EU, dovodit alespoň částečnou právní ochranu obětí sexuálního násilí, kterou má poskytovat požadavek výslovného souhlasu se sexuálním stykem.

\section{DEFINICE AFFIRMATIVE CONSENT}

Ačkoli žádná jediná obecně uznávaná definice výslovného souhlasu se sexuálním stykem neexistuje, lze vymezení affirmative consent nalézt jak v odborné literatuře, tak př́ímo $\mathrm{v}$ právních normách, které tento institut upravují. V zásadě jsou tyto definice přes drobné nepatrné odchylky totožné a vycházejí ze stejné myšlenky. Pro účely tohoto článku jsem se rozhodla využít formulaci, kterou používá státní Univerzita v New Yorku, nebot' mi připadá jednoduše uchopitelná a jasně strukturovaná.

Na základě této definice je výslovným souhlasem se sexuálním stykem zamýšleno vědomé, dobrovolné a společné rozhodnutí všech zúčastněných zapojit se do sexuální aktivity. Souhlas může být učiněn verbálně nebo neverbálním projevem, a to za předpokladu, že toto slovní vyjádření nebo jednání představuje jasný souhlas a vưli zúčastnit se sexuální aktivity. Mlčení nebo nedostatek obrany nikdy nemůže vyjadřovat souhlas. Definice souhlasného projevu vůle se sexuálním stykem je totožná pro všechny osoby bez ohledu na pohlaví, sexuální orientaci či genderovou identitu.

Vedle výše uvedeného musí být splněny vždy následující předpoklady:

- souhlas s jakoukoliv jinou sexuální aktivitou nebo předchozí souhlas se sexuálním stykem nevytváŕí automaticky předpoklad souhlasu s další sexuální aktivitou;

- souhlas je vyžadován bez ohledu na to, zda osoba, která iniciuje sexuální jednání je pod vlivem alkoholu či drog;

- souhlas může být v průběhu sexuálního aktu kdykoliv odvolán;

- souhlas nemůže být dán osobou, jež $\mathrm{k}$ jeho udělení není způsobilá pro nedostatek rozpoznávací schopnosti, a to např́íklad pokud se nachází v bezvědomí, ve spánku, je pod vlivem alkoholu nebo drog, nemá dostatek mentální kapacity či z jiného důvodu není schopna rozpoznat své jednání;

- souhlas nemůže být rovněž udělen, pokud je důsledkem nátlaku, násilí, zastrašování, nebo hrozby násilí;

- $\quad \mathrm{v}$ př́ípadě, že byl souhlas odvolán, sexuální aktivita musí být okamžitě ukončena. ${ }^{1}$ Z popsaných bodů je zřejmé, že výslovný souhlas se sexuálním stykem nelze nijak generalizovat, nýbrž záleží na individuálních okolnostech, a každý sexuální akt vyžaduje od všech aktérů nový souhlas s jeho uskutečněním. Samožrejmě je rovněž třeba zohledňovat situace, které udělení souhlasu vůbec neumožnují (věk, nedostatečná mentální kapacita, apod.).

1 Definition of Affirmative Consent. The State University of New York [online]. [cit. 2018-04-02], dostupné z 1url.cz/ztxbe. 


\section{KRÁTKÝ EXKURZ DO HISTORIE ZAVEDENÍ POLITIKY AFFIRMATIVE CONSENT}

Jak jsem již zmínila v úvodu, průkopníkem zavedení principu affirmative consent byly Spojené státy americké, a to konkrétně Kalifornie. Důvodem byl zvyšující se počet oznamování sexuálního násilí na studentských kampusech. Kalifornská vláda proto představila zákon, jenž ukládá všem univerzitám a dalším školským zařízením vyššího vzdělávání přijmout opatření, která budou zajištovat dostatečnou ochranu obětem sexuálního násilí včetně zřízení speciálních krizových center. ${ }^{2} \mathrm{~V}$ př́ípadě, že by univerzity požadované opatření nepřijaly, ztratily by nárok na poskytování finančních dotací ze strany státu. Současně zákon stanovil, že sexuálnímu styku musí předcházet výslovný souhlas projevu vůle všech participujících. ${ }^{3}$

Následně tento právní koncept přijaly i další americké státy, a to např́íklad New York nebo Illinois. Další státy USA pak přijetí podobného zákona plánují či už projednávají ve schvalovacím procesu (např. Iowa, Nebraska). Některé univerzity přijaly univerzitní politiku spolu s opatřeními vůči sexuálnímu násilí dokonce z vlastní inciativy (např. Maine) ${ }^{4}$

Vyvíjející se snahy v oblasti potírání sexuálního násilí v USA tak změnily původně uznávaný princip „no means no“ na „yes means yes“. Doktrína „no means no“ spočívá $\mathrm{v}$ tom, že obět' sexuálního útoku musí dát pachateli výslovně najevo, že s jeho jednáním nesouhlasí. „Yes means yes“ jde ještě dál, nebot’ vyžaduje od zapojených do sexuální aktivity jednoznačný souhlas. Již tedy nestačí jen to, že potenciální obět' se stykem explicitně nesouhlasí. ${ }^{5}$

\section{PRÁVNÍ ÚPRAVA V EVROPĚ S VAZBOU NA LISTINU ZÁKLADNÍCH PRÁV EU}

Hned na úvod v této kapitole je nutné zmínit, že Evropská unie je v oblasti sexuálního násilí a potažmo násilí na ženách velmi aktivní a snaží se na tento problém poukazovat prostřednictvím různých forem. Komise u př́ležitosti Mezinárodního dne proti násilí na ženách dne 24. 11. 2017 vydala prohlášení, jehož smyslem bylo zdůraznit, že se jedná o závažný problém, který vyžaduje soustavnou práci na jeho odstranění. Komise rovněž zahájila kampaň nazvanou NON.NO.NEIN - Řekni NE! Stop násilí na ženách. $V$ rámci této kampaně vyčlenila prostředky pro členské státy, aby je použily na efektivnější boj proti násilí páchaném na ženách. Komise se rovněž významně angažuje

2 LASKY, J.: Sexual assault on campus. Farmington Hills: Greenhaven Press, 2016.

Kalifornie. Senate Bill No. 967, 28. 9. 2014. [online]. [cit. 2018-04-05], dostupné z 1url.cz/Dtx5Z.

4 Consent and Respect: Affirmative Consent. Affirmative Consent Laws (yes means yes) [online]. [cit. 201805-02], dostupné z http://affirmativeconsent.com/affirmative-consent-laws-state-by-state/.

5 LITTLE, N. J.: From no means no to only yes means yes. The rational results of an affirmative consent standard in rape law. Vanderbilt Law Review, 2005, č. 4, s. 1321-1364. 
v otázce přistoupení Evropské unie k Úmluvě Rady Evropy o prevenci a boji proti násilí na ženách a domácímu násilí (Istanbulská úmluva). ${ }^{6}$

V návaznosti na výše uvedené je také vhodné poukázat na čl. 67 odst. 3 Smlouvy o fungování Evropské unie, jenž stanoví, že Unie usiluje o zajištění vysoké úrovně bezpečnosti prostřednictvím opatření pro předcházení trestné činnosti, rasismu a xenofobii a boje proti nim, prostřednictvím opatření pro koordinaci a spolupráci mezi policejními a justičními orgány a jinými př́islušnými orgány, jakož i prostřednictvím vzájemného uznávání soudních rozhodnutí v trestních věcech, a je-li to nezbytné, prostřednictvím sbližování předpisů trestního práva. Ve světle tohoto článku je zřejmé, že sbližování právních předpisů $\mathrm{v}$ oblasti trestního práva je jedním z cílů EU a mělo by se to tedy pochopitelně týkat i sexuálního násilí. Je ovšem otázkou, do jaké míry je tato harmonizace možná, zejména s ohledem na odst. 1 téhož článku, který Unii ukládá tvořit prostor svobody, bezpečnosti a práva při respektování základních práv a různých právních systémů a tradic členských států. ${ }^{7}$ Je zřejmé, že v tomto směru hrozí největší stř̌et, protože každá $\mathrm{z}$ jednotlivých zemí se $\mathrm{k}$ sexuálnímu násilí staví jinak, a to co je $\mathrm{v}$ jedné zemi považováno již za sexuální harašení, může být v druhé zemi vnímáno jako běžné chování.

Co se týče konkrétně Listiny základních práv EU (dále jen „Listina“), asi nelze př́liš diskutovat o tom, že problematiku sexuálního násilí a zásadu affirmative consent žádným speciálním článkem nepokrývá. Této tématice je proto nejbližší především 1. hlava Listiny, a to část zabývající se důstojností. Konkrétně Listina v tomto směru stanoví právo nedotknutelnosti lidské důstojnosti, právo na život, právo na nedotknutelnost lidské osobnosti, zákaz mučení a nelidského či ponižujícího zacházení anebo trestu a konečně zákaz otroctví a nucené práce. Dále by sem bylo možné zařadit také právo na svobodu a bezpečnost a rovněž zákaz diskriminace na základě pohlaví. ${ }^{8}$

Obecně platí, že povinnost respektovat základní práva obsažená v Listině je pro členské státy závazná, pokud jednají v oblasti působnosti práva Unie. Jestliže se tedy jedná o př́pad, který probíhá pouze na úrovni vnitrostátního práva, členský stát není povinen při svém rozhodování Listinu aplikovat.

Rovněž pokud se podíváme na judikaturu Evropského soudu pro lidská práva, je tato $\mathrm{v}$ souvislosti s touto tématikou poměrně velmi skoupá, a to především co se týče požadavku výslovného souhlasu se sexuálním stykem. V tomto ohledu si však dovolím zmínit př́pad M. C. vs. Bulharsko, který lze v souvislosti se sexuálním násilím považovat za zásadní a průlomový. $V$ daném případě stěžovatelka namítala, že bulharské právo a soudní praxe neposkytuje dostatečnou ochranu vůči znásilnění a sexuálnímu zneužití, když jsou trestně stíhány toliko př́ípady, u nichž je prokázáno, že se obět' aktivně bránila. V tomto směru tak stěžovatelka dovozovala porušení článku 3 Úmluvy o ochraně lidských práv a základních svobod, (tj. zákaz nelidského zacházení), dále článku 8 (právo na respektování soukromého a rodinného života), článku 13 (právo na účinný právní

6 Stop violence against women. Statement by the European Commission on the International Day for the Elimination of Violence against Women. European Commission [online]. [cit. 2018-05-02], dostupné z http://europa.eu/rapid/press-release_STATEMENT-17-4848_en.htm.

7 Smlouva o fungování Evropské Unie 2012/C 326/01 ze dne 26. 10. 2012, Úř. věst. C 326, 26. 10. 2012, s. 47-199. Dostupné z https://1url.cz/YMzdo.

8 Listina základních práv Evropské unie 2012/C 326/02 ze dne 26. 10. 2012 Úřr. věst. C 326, 26. 10. 2012, s. 391-407. Dostupné z 1url.cz/Wtx5I. 
prostředek nápravy) a konečně článku 14 (zákaz diskriminace). Pokud bych měla velmi krátce shrnout skutkové okolnosti prípadu, tak stěžovatelka tvrdila, že byla opakovaně znásilněna ve věku 15 let o několik let staršími muži, které znala. S ohledem na svůj věk a psychickou nevyspělost se však nedokázala aktivně bránit a pasivně proto na sobě strpěla vykonání soulože, byt' se stykem nesouhlasila. Stěžovatelka rovněž uváděla, že vyšetřující orgány se $\mathrm{k}$ celé situaci stavěly laxně a př́ípad náležitě neprošetřily. Evropský soud pro lidská práva dospěl k názoru, že skutečně došlo k porušení článků 3 a 8 . Porušení článku 13, tedy porušení práva na účinný právní prostředek nápravy neshledal a v této souvislosti se již pak ani blíže nezabýval námitkou porušení zákazu diskriminace. Evropský soud pro lidská práva uvedl, že Bulharsko je zavázáno k dodržování Úmluvy o ochraně lidských práv a základních svobod a musí tak přijmout legislativu, která bude trestat znásilnění a současně tuto legislativu aplikovat prostřednictvím efektivního vyšetřování a trestního stíhání. Soud rovněž ve svém rozhodnutí poznamenal, že historicky bylo možné se dopustit znásilnění jen tehdy, pokud pachatel donutil obět' ke styku násilím přes její fyzický odpor. Od oběti se tedy vyžadovalo, aby se aktivně bránila. I když se pak ve většině evropských zemí nadále uplatňuje podmínka násilného jednání, nebylo v daném prrípadě klíčové užití násilí, nýbrž to, že obět' se sexuálním stykem nesouhlasila. ${ }^{9}$

$\mathrm{Na}$ tomto prrípadě lze tedy demonstrovat, že pokud bude členský stát rozhodovat př́pad trestného činu sexuálního násilí v rámci unijního práva, mohou se občané tohoto státu dovolávat Listiny, a to zejména tehdy, pokud je právní úprava daného státu pro oběti sexuálních trestných činů méně př́znivá. Jak již zmiňoval Evropský soud pro lidská práva, velké množství členských států stále pro spáchání trestného činu znásilnění vyžaduje úmysl pachatele a užití násilí nebo hrozby násilí. Při užití principu affirmative consent je však zřejmé, že podmínka násilí odpadá, nebot' z legální definice affirmative consent lze dovodit, že k sexuálnímu útoku může dojít, aniž by si pachatel vynutil sexuální styk použitím násilí nebo jeho reálnou hrozbou.

Ve světle rozhodnutí M. C. vs. Bulharsko se proto domnívám, že oběti pocházející ze členských států, které pojímají trestný čin znásilnění značně formalisticky, a zároveň se bude jednat o př́pady, které budou umožňovat aplikaci Listiny, se mohou dovolávat jejího porušení, a to především práva na nedotknutelnost lidské osoby, lidské důstojnosti a zákazu ponižujícího jednání, zákazu diskriminace či prrípadně dalších souvisejících práv. Aplikace Listiny v takovýchto př́ípadech je pak o to významnější, že se jedná, na rozdíl od Úmluvy o ochraně lidských práv a základních svobod, o př́mý pramen unijního práva. Konkrétní možné využití v této problematice však ukáže pochopitelně až rozhodovací praxe Soudního dvora EU.

$\mathrm{V}$ rámci tohoto článku se nelze pochopitelně věnovat právním úpravám všech členských států. $\mathrm{V}$ následujících podkapitolách se proto budu v krátkosti zabývat vybranými členskými státy, jež se od tradičního pojetí požadavku násilí u znásilnění odchýlily, a príjaly právní úpravu ztotožňující se s doktrínou affirmative consent nebo se k ní alespoň přbližily.

9 Case of M.C. v. Bulgaria. Application no. 39272. Council of Europe: Stop domestic violence against women [online]. [cit. 2018-04-15], dostupné z 1url.cz/0tx59. 


\subsection{NĚMECKO}

Jedna ze členských zemí, která se rozhodla zrušit zásadu nutnosti prokázání užití násilí, resp. jeho hrozby, je Spolková republika Německo. Německo změnou právní úpravy reagovalo především na rostoucí útoky se sexuálním podtextem spojené s př́livem uprchlíků z východních zemí. Novela trestního zákoníku ohledně skutkové podstaty znásilnění byla schválena na konci roku 2016. V důsledku této změny byly do trestního zákoníku vloženy i dva nové trestné činy, a to sexuální harašení a sexuální násilí spáchané ve skupině. Dle předchozí právní úpravy se bylo možné dopustit trestného činu znásilnění jen tehdy, pokud byl pohlavní styk vynucen násilím, pod jeho hrozbou nebo za využití nechráněné situace. Nyní stačí, pokud bude v trestním řízení prokázáno, že obět' se stykem nesouhlasila. Německo tak výslovně nepožaduje, aby k sexuálnímu aktu došlo pouze na základě výslovného souhlasu zúčastněných, nýbrž zvolila mírnější formu ochrany, tedy ne znamená ne. ${ }^{10}$

\section{2 ŠVÉDSKO}

Další ze zemí Evropské unie, která se rozhodla přistoupit ke změně legislativy v návaznosti na zvyšující se sexuální útoky, je Švédsko. Švédsko je dokonce považováno za zemi s nejvyšším počtem oznámených znásilnění. ${ }^{11}$

Návrh změny právní úpravy vypracovaný švédskou vládou lze považovat za poměrně komplexní ochranu obětí sexuálního napadení, nebot' se nezabývá pouze podmínkami výslovného souhlasu se sexuálním stykem, ale i dalšími souvisejícími aspekty spojenými se sexuálním násilím. Mezi ně patři například zavedení nové skutkové podstaty znásilnění z nedbalosti a nedbalostní sexuální zneužití. Název těchto trestných činů může samozřejmě vyvolávat otázky, jak je možné provést znásilnění toliko v nedbalostní formě, když obvykle je ke spáchání znásilnění zapotřebí úmyslu pachatele. Švédská vláda má však zavedením těchto nových skutkových na mysli situace, kdy si někdo není jistý, zda je výslovný souhlas k sexuálnímu styku dán, resp. zda trvá, ale přesto v sexuální aktivitě pokračuje.

Za stěžejní lze v navrhované změně právní úpravy považovat také obrácení důkazního břemene a vypuštění podmínky násilí. Obět’ tak již nebude muset prokazovat, že se sexuálním stykem nesouhlasila, ale naopak to bude pachatel, který bude muset prokázat, že mu obět' k sexuální aktivitě udělila souhlas. ${ }^{12}$ Jednu dobu bylo dokonce diskutováno, Že by souhlas se sexuálním stykem měl být udělován v písemné formě, aby se tak předešlo jakýmkoliv nedorozuměním a nebylo pochyb o tom, že k sexuálnímu aktu došlo dobrovolně, od toho však bylo upuštěno.

10 HÖRNLE, T.: The New German Law on Sexual Assault and Sexual Harassment. German Law Journal, 2017, č. 6, s. 1309-1330. [cit. 2018-04-16], dostupné z 1url.cz/Ntx5P.

11 Reality Check: Is Malmo the "rape capital" of Europe?. BBC [online], 2017 [cit. 2018-05-01], dostupné z 1 url.cz/Ctx 5Y.

12 New sexual offence legislation based on consent. Government offices of Sweden [online]. [cit. 2018-05-01], dostupné z 1 url.cz/btxbM. 


\subsection{SPOJENÉ KRÁLOVSTVÍ}

Ve Spojeném království upravuje sexuální trestné činy Sexual Offences Act z roku 2003, jenž definuje znásilnění následujícím způsobem:

Osoba A se dopustí znásilnění pokud:

a) úmyslně svým penisem vnikne do vagíny, anusu nebo úst osoby B;

b) osoba B s takovouto penetrací nesouhlasí;

c) osoba A nemá žádný přesvědčivý důvod domnívat se, že osoba B s penetrací souhlasí.

Z popsané definice je zřejmé, že Spojené království rovněž prosazuje politiku „no means no“, je však genderově jednostranně zaměřená, když stricto sensu nepřipouští, že by se znásilnění mohla dopustit žena. Vedle znásilnění pak zákon o sexuálních trestných činech rozeznává trestný čin přinucení k sexuálnímu styku bez souhlasného jednání druhé osoby. I zde však z definice tohoto trestného činu lze dovodit, že uvažuje o pachateli trestného činu výhradně jako o muži. Žena se ovšem může dopustit sexuálního napadení. ${ }^{13}$

\section{4 ŠPANĚLSKO A ČESKÁ REPUBLIKA}

Výše popsané právní úpravy dokazují, že legislativa ohledně sexuálního násilí je v Evropě poměrně nejednotná a vykazuje mezi jednotlivými zeměmi rozdílné přístupy. Jako další př́iklad si dovolím uvést nyní aktuální případ, který se odehrál ve Španělsku. Přibližně před dvěma roky během oslav jednoho z populárních španělských svátků skupina místních mladíků znásilnila mladou ženu a celý průběh si navíc natočila na mobilní telefon a tuto nahrávku zveřejnila na internetu. Soud však útočníky neodsoudil za znásilnění, nýbrž pouze za sexuální zneužití, přičemž tresty za tento čin jsou ve Španělsku výrazně nižší než tresty za znásilnění. Verdikt byl odůvodněn tím, že nebylo prokázáno, že k sexuálnímu styku došlo za užití, resp. pohrůžky násilí. Toto rozhodnutí vyvolalo ve Španělsku obrovské nevole a po celém Španělsku probíhají bouřlivé demonstrace domáhající se změny rozsudku. V této souvislosti si dovolím poznamenat, že útočníci byli odsouzeni k nepodmíněnému trestu odnětí svobody ve výši 9 let, což je však na české poměry za trestný čin proti lidské důstojnosti v sexuální oblasti poměrně vysoký trest. ${ }^{14} \mathrm{~V}$ prrípadě základní skutkové podstaty znásilnění hrozí pachateli dle českého trestního zákoníku trest odnětí svobody na šest měsíců až pět let. Pokud bude znásilnění provedeno souloží nebo jiným obdobným způsobem bude pachatel potrestán odnětím svobody v rozmezí mezi dvěma až deseti lety. ${ }^{15}$ Útočníci tak dostali trest téměř při horní hranici trestní sazby za znásilnění v České republice, a to byli stíháni za sexuální zneužití, tedy za skutek považovaný za méně závažný, než je znásilnění. Uložení takto vysokého trestu za podobný skutek bych v České republice považovala za velký úspěch, nebot' pokud není oběti způsobena vážná újma na zdraví, tresty se pohybují

13 Sexual Offences Act 2003. Legislation.gov.uk [online]. [cit. 2018-04-04], dostupné z https://www .legislation.gov.uk/ukpga/2003/42/section/1.

14 ORTEGA DOLZ, P.: Sentencia del caso de la manada. La Manada se libra de la violación. El País [online], 2018 [cit. 2018-05-04], dostupné z 1url.cz/HtxbL.

15 Zákon č. 40/2009 Sb., trestní zákoník, ve znění pozdějších předpisů. 
spíše ve spodní hranici trestní sazby. Nutno zdůraznit, že české trestněprávní normy vyžadují pro spáchání znásilnění rovněž zavinění ve formě úmyslu a použití násilí, pohrůžky násilí nebo pohrůžky jiné těžké újmy či zneužití bezbrannosti oběti. Česká právní úprava se tak řadí mezi členské státy, které stále setrvávají na původním konceptu znásilnění. Za násilí se pak dle odborné literatury a soudní praxe považuje ,použití fyzické síly ze strany pachatele za účelem překonání nebo zamezení vážně míněného odporu znásilňované osoby a dosažení pohlavního styku proti její vưli““. ${ }^{16}$ Dle mého názoru však už jen podmínka vážně míněného odporu je značně př́sná a vůbec nepamatuje na situace, kdy se obět' dostane do takového šoku, že není schopna adekvátně reagovat a raději pachateli $v$ jeho požadavku vyhoví, aby předešla případné větší újmě. Dle informací uveřejněných na webu České ženské lobby zažilo fyzické nebo sexuální násilí 32\% českých žen. ${ }^{17}$ Oproti předchozímu trestnímu zákonu č. 140/1961 Sb., který řadil mezi trestné činy proti lidskosti pouze znásilnění, pohlavní zneužití a soulož mezi př́buznými, však aktuální trestní zákoník definuje mimo jiné trestný čin sexuálního nátlaku. I pro spáchání sexuálního nátlaku je však stále vyžadováno násilné jednání nebo alespoň pohrůžka těžké újmy. ${ }^{18}$ Současný stav v České republice tak lze s ohledem na vývoj a posun v oblasti sexuálního násilí považovat za nedostatečný.

\section{ZAMYŠLENÍ SE NAD MOŽNÝMI RIZIKY V PǨÍPADĚ STRIKTNÍ APLIKACE PRINCIPU AFFIRMATIVE CONSENT}

Z vymezení affirmative consent vyplývá, že souhlas $\mathrm{k}$ sexuálnímu styku nemůže být udělen osobou pod vlivem alkoholu nebo drog. Tato jednoduchá konstrukce již však př́liš nepamatuje na př́ípady, kdy jsou oba účastníci sexuálního aktu pod vlivem návykové látky nebo alkoholu. Vyvstává tak otázka, zda by mohl být někdo v tomto př́ipadě eventuálně odpovědný za spáchání sexuálního násilí, resp. znásilnění? Pokud ano, podle jakých parametrů by se pachatel posuzoval? V prrípadě heterosexuálního styku by byl za pachatele automaticky označen muž? Nebo by se (v praxi velmi obtížně) prokazovalo, který z účastníků byl méně schopen rozpoznat a ovládnout své jednání a tím by se tedy jednalo o obět? Byt' se tato situace může zdát poněkud absurdní, není vyloučeno, aby $\mathrm{k}$ něčemu podobnému skutečně došlo, přičemž v takovémto př́ipadě může mít užití principu affirmative consent pro domnělého pachatele zcela fatální důsledky. Názorně si to můžeme představit na př́kladu studentského večírku, kde se seznámí dva studenti a v důsledku alkoholového opojení mezi nimi dojde k sexuálnímu styku. Následující den však jeden z participujících začne tvrdit, že k souloži nedal souhlas a byl tak znásilněn. $V$ tomto okamžiku je samozřejmé, že obviněný se ocitne v nesmírně obtížně pozici, nebot' i kdyby eventuálně prokázal, že styk byl dobrovolný, tak platný souhlas mu ani ze strany druhé osoby pro opilost být dán nemohl. Velmi extenzivním výkladem

16 ŠÁMAL, P. a kol.: Trestni zákonik. Komentář. Praha: C.H. Beck, 2012.

17 STOP násilí na ženách. Česká ženská lobby [online]. [cit. 2018-05-10], dostupné z https://czlobby.cz/cs /projekty/stop-nasili-na-zenach.

18 Zákon č. 140/1961 Sb., trestní zákon, ve znění pozdějších předpisů. 
by tak bylo možné dovodit, že sex by měl probíhat výhradně mezi stř́zlivými osobami, což je pochopitelně nerealizovatelné.

\subsection{KDYŽ ANO ZNAMENÁ NE A NE ZNAMENÁ ANO}

V České republice je judikatura ohledně udělení výslovného souhlasu velmi strohá, resp. téměř žádná. Nedávno se však jeden př́ípad zabývající se touto tématikou dostal až před Nejvyšší soud. Skutkový stav spočíval v tom, že se obviněný prostřednictvím internetové komunikace s poškozenou dohodl na poskytnutí sexuálních služeb včetně konkrétních sadomasochistických praktik, a to za finanční odměnu. Za účelem realizace dohody se následně obviněný s poškozenou sešel a provozoval s ní dohodnuté sexuální praktiky, ačkoli poškozená s nimi nesouhlasila, projevovala známky odporu a podvolila se jednání obviněného ze strachu, přičemž posléze řekla, že už žádné peníze nechce, a projevila snahu se vzdálit. Obviněný sjednanou finanční odměnu nakonec poškozené skutečně neuhradil a ta na něj podala o několik měsíců později trestní oznámení pro znásilnění.

Soud prvního stupně uznal obviněného vinným ze zločinu znásilnění a odsoudil jej k nepodmíněnému trestu odnětí svobody v délce 7 let. Proti tomuto rozhodnutí podal obviněný odvolání, kdy odvolací soud posoudil věc zcela jinak a rozsudek soudu prvního stupně v plném rozsahu zrušil a rozhodnul o zproštění obžaloby obviněného. Soud druhého stupně odůvodnil toto rozhodnutí tím, že za situace, kdy veškeré realizované praktiky byly předem domluveny, nebylo obviněnému poškozenou z jeho pohledu dostatečně signalizováno, že s jeho jednáním nesouhlasí, a proto nelze učinit závěr o úmyslu obviněného spáchat trestný čin. Podle odvolacího soudu není zřejmé, že by obviněný věděl, že se při svém počínání pohybuje již za hranicí akceptovatelnou poškozenou.

Proti rozhodnutí odvolacího soudu podal v neprospěch obviněného dovolání nejvyšší státní zástupce, a to z toho důvodu, že měl za to, že rozhodnutí spočívá na nesprávném právním posouzení skutku nebo jiném nesprávném hmotněprávním posouzení. Ve věci bylo nutno podle nejvyššího státního zástupce vycházet z procesně dovozeného skutkového zjištění nalézacího soudu, podle kterého bylo prokázáno, že obviněný o nesouhlasu poškozené s prováděnými sexuálními praktikami věděl a s překonáním jejího odporu byl srozuměn. Dovolatel měl v tomto směru za to, že odvolací soud dospěl k jiným skutkovým závěrům, než soud prvního stupně, aniž by ovšem prováděl dokazování. Nejvyšší soud posoudil dovolání jako př́ípustné, ale neztotožnil se s právním názorem dovolatele, nebot' měl za to, že odvolací soud skutková zjištění nezpochybnil, nýbrž je pouze rozdílně interpretoval. Podstatou napadeného zproštujícího rozsudku je odlišné právní posouzení subjektivní stránky činu, $\mathrm{v}$ tomto př́ípadě úmyslu obviněného donutit poškozenou k souloži. Dle Nejvyššího soudu ovšem jednání obviněného nevykazovalo zákonné znaky skutkové podstaty trestného činu znásilnění, nebot' nebylo zjištěno zavinění ve formě úmyslu a $\mathrm{v}$ jednání obviněného neshledal znaky ani jiného trestného činu. Nejvyšší soud proto dovolání nejvyššího státního zástupce jako zjevně neopodstatněné odmítl. ${ }^{19}$

19 Usnesení Nejvyššího soudu ze dne 14. února 2018, spis. zn. 7 Tdo 119/2018. [cit. 2018-04-30]. Dostupné z http://kraken.slv.cz/7Tdo119/2018. 
Poměrně překvapující rozhodnutí Nejvyššího soudu tak ukazuje, že požadavek souhlasného projevu vůle nemá v českém právním prostředí tak prrísné vymezení jako je tomu napríílad u angloamerického práva. $Z$ výše popsaného případu lze však jasně dovodit, že české soudy při posuzování prrípadu hodnotí vždy relevantní individuální okolnosti a nestaví se k bezbřehé ochraně potenciální oběti. Poukazuje však i na již zmiňované nedostatky českého trestního práva, protože jednání obviněného by se dalo označit minimálně za nevědomou nedbalost, nicméně vzhledem $\mathrm{k}$ tomu, že český trestní zákoník vyžaduje pro spáchání znásilnění zavinění ve formě úmyslu, obviněný se vyhnul jakémukoliv prrípadnému potrestání.

\section{ZÁVĚR}

Článek si kladl za cíl analyzovat, zda je možné při aplikaci unijního práva v oblasti sexuálního násilí, a to zejména $\mathrm{v}$ souvislosti s principem affirmative consent využít jednotlivé články Listiny základních práv EU. Vzhledem k tomu, že k této problematice existuje velmi málo odborné literatury, byly to úvahy především na teoretické bázi vycházející z př́ípadu řešeného před Evropským soudem pro lidská práva.

$\mathrm{V}$ tomto směru jsem dospěla $\mathrm{k}$ názoru, že byt' je úprava Listiny ohledně trestných činů v sexuální oblasti velmi strohá, mám za to, že není do budoucna zcela vyloučeno, dovolávat se za určitých podmínek při uplatňování principu affirmative consent Listiny. Je však nutné zohlednit, že každý právní řád ze států Evropské unie obsahuje podrobnější úpravu sexuálních trestných činů, a proto bude vždy nutné vyhodnotit, zda základní práva zaručená $\mathrm{v}$ právním řádu Unie poskytují vyšší ochranu než vnitrostátní právo a zda mají členské státy povinnost přijmout nějaké opatření, aby jejich národní úprava vyhovovala dikci Listiny. Rovněž ovšem nelze opomenout tendence členských států měnit svou vnitrostátní legislativu v oblasti sexuálního násilí, což jen podtrhuje fakt, že právní úprava na úrovni evropského a mezinárodního práva začíná být považována za nedostatečnou. Trendy v potírání sexuálních trestných činů jsou tedy bezesporu velmi dynamické, což dosvědčuje i přijetí tzv. Istanbulské úmluvy na poli Rady Evropy, která poskytuje daleko specifičtější ochranu obětem sexuálního násilí, ačkoli je zaměřena jen na násilí páchané na ženách a nelze ji tedy vztáhnout na násilné útoky vůči mužům či dětem (byt' $\mathrm{v}$ tomto př́padě záleží, jak moc striktně bude Istanbulská úmluva vykládána). Nutno ovšem zmínit, že přijetí Istanbulské úmluvy provázejí od samého počátku rozporuplné debaty, kdy ne všechny státy považují text této úmluvy za akceptovatelný, a to zejména s poukazem na to, že se jedná o oblast, která by měla zůstat ponechána v jurisdikci jednotlivých států. V České republice nebyla Istanbulská úmluva doposud ratifikována a tento další krok je předmětem rozsáhlých diskusí, které mnohdy vykreslují Instanbulskou úmluvu jako nástroj na potírání genderu. Dle mého názoru je takovýto výklad značně přehnaný a zkreslený, nebot' z textu úmluvy rozhodně nelze dovodit, že by jejím smyslem byla snaha o zrušení tradičního modelu rodiny, nýbrž se jedná o právní normu, která zásadním způsobem posiluje postavení žen v případě, kdy přišly do styku s násilím. Významnost této úmluvy lze dovodit i z toho, že o přistoupení $\mathrm{k}$ ní jedná i samotná Evropská unie a je jen otázkou času, kdy tak učiní. 
Dá se tak shrnout, že použití Listiny je, co se týče institutu affirmative consent spíše omezené a existují a připravují se účinnější instrumenty, které mohou oběti sexuálního násilí využít, at' již v některých státech přímo na úrovni vnitrostátního práva, nebo v rámci práva evropského, a to např́klad právě odkazem na Istanbulskou úmluvu.

Mgr. Sabina Krajíčková

Katedra evropského práva Právnické fakulty Univerzity Karlovy

sabina.krajickova@gmail.com 